\title{
The Speed of Learning about Firms' Profitability and their Price Multiples: A Global Perspective
}

\author{
PANKAJ K. JAIN AND UDOMSAK WONGCHOTI*
}

\begin{abstract}
This paper is an application of learning models in valuation of stocks listed on 48 international stock exchanges. We present global evidence that a lower $\mathrm{M} / \mathrm{B}$ ratio is associated with lower uncertainty about a firm's profitability which questions the linkage between low $\mathrm{M} / \mathrm{B}$ ratio and high risk. We make new discoveries about the speed of learning about firms' profitability in markets that offer different market designs and legal frameworks. Learning is faster in economically developed markets, on fully automated stock exchanges, and in countries where prohibitions on insider trading laws are enforced. Better market design particularly facilitates the learning process in emerging markets because their financial disclosure systems are not as robust as developed markets.
\end{abstract}

JEL Classification Codes: G12, G14, G15

Key Words: Market to book ratio

* Jain is from Fogelman College of Business and Economics, The University of Memphis, USA and Wongchoti is from Massey University, Palmerston North, New Zealand. Please send correspondence to Pankaj Jain, FCBE 425, University of Memphis, Memphis, TN 38111, Phone (901) 678 3810, Fax (901) 678 0839, Email: pjain@memphis.edu or J.Wongchoti@massey.ac.nz. We would like to thank Kelli Jeanne Kirk, Jared Cahan, and Craig Goodwin for research assistance, comments and suggestions. All errors are our responsibility. 


\title{
The Speed of Learning about Firms' Profitability and their Price Multiples: A Global Perspective
}

\begin{abstract}
This paper is an application of learning models in valuation of stocks listed on 48 international stock exchanges. We present global evidence that a lower $\mathrm{M} / \mathrm{B}$ ratio is associated with lower uncertainty about a firm's profitability which questions the linkage between low $\mathrm{M} / \mathrm{B}$ ratio and high risk. We make new discoveries about the speed of learning about firms' profitability in markets that offer different market designs and legal frameworks. Learning is faster in economically developed markets, on fully automated stock exchanges, and in countries where prohibitions on insider trading laws are enforced. Better market design particularly facilitates the learning process in emerging markets because their financial disclosure systems are not as robust as developed markets.
\end{abstract}


Market to book (M/B) ratio is a widely used valuation ratio in the equity markets around the world. Among investors, high (low) M/B stocks typically represent expensive (cheap) stocks due to their high (low) growth potential. In recent years, financial researchers have accepted the market to book ratio (or its reciprocal, book to market ratio) as one of the key variables that explain the cross-sectional variation in expected stock returns. Fama and French $(1992,1993)$ provide the long-horizon evidence in the US market that expected stock returns decrease with $\mathrm{M} / \mathrm{B}$ ratio. Numerous researchers confirm the relationship in the international markets. However, the interpretation of such relationship has been controversial. In the spirit of market efficiency, Fama and French $(1993,1995)$ suggest that M/B ratio could be the proxy of a systematic risk factor in the framework of their three factor model. In contrast, Lakonishok, Shleifer, and Vishny (1994) provide a behavioral explanation that investor overreaction in extrapolating past performance is responsible for the association between returns and M/B ratio. Daniel and Titman (1997) more emphatically reject the existence of M/B ratio as a systematic risk factor which is priced. Instead, they find that firms with similar M/B ratio simply share firm characteristic such as a line of business. M/B differences have no explanatory power once these characteristics are controlled for. Shefrin and Statman (1995) perform a survey on a number of investors about their perceptions on $\mathrm{M} / \mathrm{B}$ ratio and find that aggregate investors perceive high $\mathrm{M} / \mathrm{B}$ stocks as good investments. Regardless of the controversy, it is clear that $\mathrm{M} / \mathrm{B}$ ratio is crucial in understanding the dynamics of capital asset pricing and stock valuation. Most recently, $\mathrm{M} / \mathrm{B}$ ratio is being associated to the age of a firm. Pastor and Veronesi (2003) develop a model for valuing stocks in the presence of learning about average profitability. Valuation is increasing in uncertainty about future profitability. They predict that the ratio of market value to book value declines 
with firm's age as investors learn about average profitability. The model finds empirical support in a sample of NYSE firms. Specifically, market to book value of a firm declines sharply in the first few years of its existence and stabilizes after about thirteen years. The results are more pronounced for the non-dividend paying firms and robust after controlling other factors that determine $\mathrm{M} / \mathrm{B}$ ratio. Their empirical results, together with the model, help explain that the high M/B ratio phenomenon found in the NYSE during the recent years could be the result of higher number of emerging new firms (e.g. IPOs). We test this model using stock market ratios in 48 international markets. We make new discoveries about the speed of learning about firms' profitability in markets that offer different market design and legal framework.

Firms listed on international exchanges possess very distinct characteristics from NYSE firms in terms of their cash flow predictability, size, and age. The exchange design and legal environment themselves present an interesting cross sectional variety across countries. In addition to providing an out-of-sample perspective on the patterns documented by Pastor and Veronesi (2003), we investigate new hypothesis on the effects of market restructuring including improvement in market design and the enforcement of insider trading law on the speed of learning about profitability and asset prices. If learning about profitability plays an important role in determining the $\mathrm{M} / \mathrm{B}$ ratio of a firm, the inverse relation between $\mathrm{M} / \mathrm{B}$ ratio and the age of the firm should be more persistent in emerging capital markets where it takes longer to resolve the uncertainty due to poor disclosures. On the contrary, the relation between $\mathrm{M} / \mathrm{B}$ ratio and the age becomes flat (stabilized or settled) quickly in developed markets with better disclosure. 
The effects of market restructuring are even more interesting to analyze. There have been some significant improvements in recent years such as automation of financial markets and stricter enforcement of insider trading laws. These incidents make the relationship between valuation and firm age in the international context even more interesting. Important empirical questions arise as a result. Does learning about profitability exist in all markets and all industries? Does the speed of learning vary across countries and industries? Do market restructuring such as improvement in market design and the enforcement of insider trading law improve the learning process and increase the speed of learning?

Our paper also contributes to the debate on the interaction of international diversification and industrial diversification. Firms in emerging markets are typically concentrated in traditional industries where cash flow uncertainty is less severe. In contrast, the poor financial disclosures in these countries make the uncertainty more severe. Which of these two effects dominates is an empirical question.

We analyze 25,631 firms for which M/B ratio data are available on Datastream. These come from stock exchanges in 48 countries. In general, we find the supporting evidences for most of our hypotheses. First, learning curve as represented by the convex inverse relationship between M/B ratio and the firm's age is a global phenomenon. Such relationship is more striking for non-dividend paying firms as suggested by Pastor and Veronesi (2003). The inverse relationship is significant at $5 \%$ level after controlling for other factors that might explain market-to-book ratio. Second, speed of learning is faster for developed markets. Economic development and market environment are the main determinants of the speed of learning and the industry differences do not have much explanatory power. Third, the market restructuring including improvement in market design and the enforcement of insider trading 
law indeed impact the learning process as reflected in the relationship between $\mathrm{M} / \mathrm{B}$ ratio and the firm's age over time. Improvements in market design are particularly helpful in emerging markets. Emerging markets benefit more from the transparency and the informativeness afforded by electronic markets because they begin with more severe problems on the fronts of poor financial disclosure, rampant insider trading, and manipulation by brokers.

The remainder of the paper is organized as follows. The next section contains this study's hypotheses. Data sources are outlined in section II. Empirical methodology and results are presented in the following section. Section IV concludes.

\section{Testable Hypotheses}

$H 1_{0}$ : There is, in general, a learning curve in the World's financial markets. Following Pastor and Veronesi (2003), we predict that convexity induces higher M/B ratios for firms with greater uncertainty about profitability. Such relationship is presented in the following equation:

$$
\frac{M}{B}=E\{\exp [(g-r) T]\}=\exp \left[\left(\bar{g}+\sigma^{2} / 2-r\right) T\right]
$$

where $M / B$ stands for market to book ratio, $\mathrm{E}\{$.$\} is the expectations operator, g$ is the growth rate, $r$ is the stochastic discount factor, $T$ can be interpreted as the time after which firm is not expected to grow at an abnormal rate, $\exp$ stands for exponential, $\sigma^{2}$ represents the volatility of returns or uncertainty about profitability. It is a mathematical property of this equation that $\mathrm{M} / \mathrm{B}$ increases in $\sigma^{2}$. Innovation is good and innovative firms are valued highly even when their profitability is highly uncertain.

Firms just entering the market tend to possess higher uncertainty about cash flow and profitability. With learning, such uncertainties reduce over time. As a result, $\mathrm{M} / \mathrm{B}$ ratio is 
higher when the firm just enters the market. The $\mathrm{M} / \mathrm{B}$ ratio then reduces to lower level and become stabilized over time. This relationship should be more striking for non-dividend paying firms as suggested by Pastor and Veronesi (2003).

$H 2_{0}$ : The inverse relation between $\mathrm{M} / \mathrm{B}$ ratio and the age of the firm is more persistent in emerging capital markets where uncertainty is higher due to poor disclosures which also increase the amount of time it takes to resolve the uncertainties through learning. In other words, the speed of learning is faster in the developed markets where financial disclosure systems are presumably better. As the result, the relation between $\mathrm{M} / \mathrm{B}$ ratio and the age become flat (stabilized or settled) faster in developed markets than in emerging markets.

$H 3_{0}$ : Improved market design such as fully automated trading, market completeness with feasible short selling, and enforcement of insider trading laws attract more investors and analysts who in turn help speed up the learning process. Thus, M/B ratio of new firms stabilizes more quickly in automated transparent markets while the ratio tends to bounce around in opaque markets with poor disclosure and manipulative practices. The benefits of transparency resulting from better market design are likely to be higher in emerging market as follows:

\begin{tabular}{|l|l|l|l|}
\hline Market & $\begin{array}{l}\text { Beginning level of } \\
\text { learning before } \\
\text { market design } \\
\text { changes }\end{array}$ & $\begin{array}{l}\text { Ending level of } \\
\text { learning }\end{array}$ & $\begin{array}{l}\text { Difference= Marginal Effect } \\
\text { of Market Design Changes on } \\
\text { Learning }\end{array}$ \\
\hline $\begin{array}{l}\text { Developed } \\
\text { markets }\end{array}$ & $\begin{array}{l}\text { High (due to good } \\
\text { disclosure requirements } \\
\text { and legal enforcement) }\end{array}$ & High & Low \\
\hline $\begin{array}{l}\text { Emerging } \\
\text { Markets }\end{array}$ & $\begin{array}{l}\text { Low (due to poor } \\
\text { financial disclosures) }\end{array}$ & $\begin{array}{l}\text { High (due to } \\
\text { improved trade } \\
\text { transparency) }\end{array}$ & High \\
\hline
\end{tabular}




\section{Data}

Our sample consists of 25,631 firms from 48 countries listed in Table I. We gather annual time series of prices, dividend per share, market to book ratio, annual and monthly time series of returns from Datastream International tapes. We verify the accuracy of this historical data by comparing it with Compustat Global datasets and Yahoo Finance for one company in each country. The next important item we need is the age of each firm. Direct information on this variable is not available in any traditional dataset. Therefore, we follow Fama and French (2001) and Pastor and Veronesi (2003) in this regard and use the year of first appearance of any variable for a firm in the dataset as its year of birth. In Datastream, annual price tends to be the variable that becomes available first. As a result, the definition of age in our study is based primarily on the first year the annual price is available. This information is used to allocate the firm to an age category in our panel dataset. We start this process from the year 1969 and our sample ends in the year 2004. We have 36 years in all. We filter out the M/B observations of less than 0.01 and greater than 100 . This results in 177,880 firm-years.

Table 1 also shows the number of firms from each country in 2004. Morocco has the lowest number of firms and UK has the highest number of firms. The table also has information on the financial environment variables for each country. Each country is assigned the level of economic development, liberalization, the development in market design and the status on enforcement of insider trading laws based on Morgan Stanley classification, Bekaert and Harvey (1995), Henry (2000), Bhattacharya and Daouk (2002), and Jain (2004).

[Insert Table 1 here] 
Finally we obtain the intensity of trading by foreign institutions in a country's stock market from Plexus Data. The details of this dataset are described in more details in Chiyachantana et al (2004). We divide the total dollar volume of all trades undertaken by foreign institutions in a country by the total market capitalization of that country's stock market. Based on this measure we divide the sample into countries with high versus low foreign institution involvement.

\section{International evidence on $\mathrm{M} / \mathrm{B}$ vs Age relationship}

\section{A. Firm age and M/B ratio: Global vs Developed vs Emerging}

The relationship between a firm's age and market to book ratio is strikingly pervasive. Figure $1 \mathrm{a}$ and $1 \mathrm{~b}$ plots the global median and average of market to book ratio for firms of ages 1 to 20 years ${ }^{1}$. It also plots the relationship separately for developed markets and emerging markets. This classification is obtained from Morgan Stanley Capital International's website at mscidata.com.

\section{[Insert Figure $1 \mathrm{a}$ and $1 \mathrm{~b}$ here]}

First of all, the inverse relationship between M/B ratio and the firm's age, mainly in the earlier years of operation, seems to be a global phenomenon. This supports our first hypothesis. The ratio declines sharply with the firm's age during the first six years of operation. The inverse relationship continues with much flatter slope until the firm is about 12 year old. The relationship stabilizes until the firm reaches the age of 15 years old.

Interestingly, the market to book ratio rebounds after 15 years before stabilizing again at year 18. Perhaps this indicates that reputation factor kicks in at this age. It is also possible that

\footnotetext{
${ }^{1}$ Although our data starts from 1969, the plot of variables are for 20 years because the number of observation fall dramatically for data before 2 decades and makes the observed relationships less reliable and representative.
} 
firms begin to undertake aggressive growth project after their initial start-up ventures are well established. The global pattern of M/B dynamics over the age of the firm seems to closely follow that of the developed markets, indicating their bigger share of the world capitalization. Consistent with our second hypothesis, the inverse relationship between $\mathrm{M} / \mathrm{B}$ ratio and the firm's age is more persistent in the emerging markets. After 10 years, the market-to-book ratios of firms in developed markets stop declining and even rebound to yield the reversed Jshaped pattern. On the other hand, market-to-book ratios of firms in emerging markets continue to decline and even after 20 years. In terms of speed of learning, our results imply that the time required for learning in the developed markets is about 10 years versus 20 years in emerging markets. This presents an important implication to international fund managers in making cross country comparisons of financial ratios.

Table 2 provides the averages of M/B ratio for each age category for individual countries. The inverse relationship between the two measures is very pervasive. Interestingly, several countries in the Middle East and South Asia display a hump-shaped start with M/B starting low in the IPO year, picking up in the second year and then declining as usual with age.

[Insert Table 2 here]

\section{B. Firm age and M/B ratio: Dividend vs Non-dividend paying firms}

According to Pastor and Veronesi (2003), the inverse relationship between M/B ratio and the firm's age should be more striking in non-dividend paying firms. Figure $2 a$ and $2 b$ plot the relationship between M/B ratio and the firm's age for dividend paying firms and nondividend paying firms in developed and emerging markets respectively. In general, we 
confirm that dividends accelerate the learning process about profitability in the global context. This is true in both developed and emerging markets.

[Insert Figure 2a and 2b]

\section{The effects of market design and insider trading law enforcement on the learning process}

Figure 3(a) plots M/B ratio and the firm's age before and after the significant improvement of market design. The cut-off year for each country is the date of complete automation as listed in Table 1. These dates are obtained from Jain (2004) who shows that the events are associated with significant changes in the equity premium. There are several interesting observations. First, for developed markets, the upward bounce of $\mathrm{M} / \mathrm{B}$ after the firm operates for fifteen or sixteen years as seen in Figure 1a seems to disappear after the improvements in market design. Second, for emerging markets, the learning process as reflected by the inverse relationship between M/B ratio and firm's age bounces all over the place. In contrast, after big improvement in market design, the steady inverse relationship can be seen very clearly.

[Insert Figure $3 \mathrm{a}$ and $3 \mathrm{~b}$ here]

Figure 3(a) plots M/B ratio and the firm's age in markets where short selling is feasible versus those where it is infeasible. This information is obtained from Charoenrook and Daouk (2005). They study the impact of short selling constraints on the cost of equity (the discounting rate in asset pricing models, which is a denominator effect) whereas our focus on reduction in uncertainty of the cash flows through learning (a numerator effect). We observe a J-shaped relationship between $\mathrm{M} / \mathrm{B}$ and age if short selling is feasible. In contrast, the steady inverse relationship can be seen if short selling is absent.

Figure 4 represent the plot of M/B ratio and firm's age before and after the enforcement of insider trading law. The cut-off year for each country is taken from Bhattacharya and Daouk 
(2002) and is reproduced in Table 1. Interestingly, the enforcement of insider trading law also improves the learning process. For developed markets, the $\mathrm{M} / \mathrm{B}$ ratio of firms seem to be more stabilized after the insider trading law enforcement, particularly for firms older than 14 year old. For emerging markets, insider trading law also improves the learning process as can be seen from the more steadily reverse relationship between M/B ratio and the firm's age after such law enforcement. The level of $\mathrm{M} / \mathrm{B}$ ratio in developed markets is also higher before the insider trading law is in effect.

\section{[Insert Figure 4 here]}

\section{Return volatility (idiosyncratic risk) and the process of learning}

Pastor and Veronesi (2003) use residual return volatility (defined as the median idiosyncratic return volatility $\left(\mathrm{Y}_{\mathrm{i}}\right)$ calculated from the market model) as the proxy of uncertainty about future profitability. They show that volatility reduces over time as firms mature. They argue that reduced residual return volatility represents the better resolved value (through learning over time) of the stocks as the market learn more about their intrinsic values. In order to get additional insight from this perspective, we calculate simple return volatility of each stock as defined by the standard deviation of monthly returns of each stock in each year of the observation, integrate them, and plot the graphs as presented in figure 5.

[Insert figure 5 here]

Return volatility of global stocks declines over years. This is true in both developed and emerging markets. As one would expect, volatility of stocks in emerging markets is higher in magnitude than of stocks in developed markets for any given age. Combined with our results presented in earlier graphs, the learning process about profitability can only partially explain the relationship between M/B and the firm's age found in the global data. 
Specifically, it can explain the results for all firms in emerging markets and firms less than 15 year old in developed markets. It does not explain the bounce of M/B after the firm hit 15 years of age in the developed markets.

\section{E. Firm age and M/B ratio: Industry analysis}

Consistent with our hypothesis 2 , figure 6 illustrates the striking difference in $\mathrm{M} / \mathrm{B}$ vs the firm's age relationship among developed and emerging markets. However, these two groups might concentrate on specific industries. As a robustness check, we plot the $\mathrm{M} / \mathrm{B}$ vs the firm's age for all firms based on industry classification of trade and non-trade industries following Griffin and Karolyi (1998) and present the results in Figure 6. The traded firms are on the extremes with sharply declining $\mathrm{M} / \mathrm{B}$ ratio with age in emerging markets and a flat relationship with age in developed markets. Non- traded firms are enveloped between these extremes. The difference between traded and non traded goods is not significant in developed markets. However, in the emerging markets, firms that produce traded goods have a steeper slope and therefore start with a higher $\mathrm{M} / \mathrm{B}$ and end with a lower $\mathrm{M} / \mathrm{B}$ than traded goods. Nonetheless, the differences between developed and emerging markets hold in each industry group. Hence industry concentration is not the driving factor for these differences.

\section{F. Regression Analysis}

To confirm the significance of inverse relationship between M/B ratio and the firm's age for the global portfolio while controlling for other factors known to explain market-tobook ratio, we provide a simple regression analysis as follows:

Cross-sectionally, for each year: 


$$
\begin{aligned}
\log (\mathrm{M} / \mathrm{B})_{\mathrm{i}}= & \mathrm{a}+\mathrm{b} \cdot \mathrm{AGE}_{\mathrm{i}}+\mathrm{c} \cdot \mathrm{DD}_{\mathrm{i}}+\mathrm{d} \cdot \operatorname{LEV}_{\mathrm{i}}+\mathrm{e} \cdot \mathrm{SIZE}_{\mathrm{i}}+\mathrm{f} \cdot \mathrm{ROE}_{\mathrm{i}}+\mathrm{g} \cdot \operatorname{ROE}(1)_{\mathrm{i}}+ \\
& \text { h.ROE}(2)_{\mathrm{i}}+\mathrm{i} \cdot \operatorname{ROE}(3)_{\mathrm{i}}+\mathrm{j} \cdot \operatorname{RET}(1)_{\mathrm{i}}+\mathrm{k} \cdot \operatorname{RET}(2)_{\mathrm{i}}+1 \cdot \operatorname{RET}(3)_{\mathrm{i}}
\end{aligned}
$$

where $\mathrm{i}=1-\mathrm{N}, \mathrm{N}$ is the \# of firms in each year t. AGE is defined as - $1 /(1+$ Firm's Age $)$ following Pastor and Veronesi (2003). DD is the dividend dummy with value 1 for dividend paying firm and 0 otherwise. LEV is the debt ratio. SIZE is the natural log of the firm's totol asset. ROE is the return on equity and regressed up to three years following year t. RET is future annual stock return up to three years from current period.

Besides the benefits of confirming the econometric relationship between $\mathrm{M} / \mathrm{B}$ ratio and the firm's age, the above regression also provide additional insights of such relationship in calendar years. The purpose of including future returns is to control for the market's expectations of high growth which could also cause the $\mathrm{M} / \mathrm{B}$ ratio to be higher. The results are provided in Table 3.

\section{[Insert Table 3 here]}

In general, the inverse relationship between $\mathrm{M} / \mathrm{B}$ ratio and the firm's age of the Global portfolio is confirmed by the regression. The t-statistics ${ }^{2}$ over years for Age coefficient are 2.39 , which is significant at 5\% level. The signs of control variables' coefficients are all in line with Pastor and Veronesi (2003). However, it should be noted that the relationship itself is also time-varying. The negative relationship seems to be strong before 1987 and after 1993 .

In Panel B of Table 3, we divide our sample into developed and emerging markets. The coefficient on age is more negative in the emerging markets. One interpretation of this finding is that the lower quality of disclosures in emerging markets increases the uncertainties

\footnotetext{
${ }^{2}$ The t-statistics is calculated following several authors such as Jones(1993) and Chan (1988).
} 
about the cash flows of the new companies. Therefore, investors have to learn more from the company's actual cash flows than from the financial projections.

Panel $\mathrm{C}$ reports the effect of short selling on the learning environment. The inverse relationship between firm age and $\mathrm{M} / \mathrm{B}$ ratio is steeper in the markets where short selling is not feasible. In Panel D, we examine the effects of foreign institutional investment in a country's stock markets. Based on this intensity of institutional trading observed in Plexus database, we divide the sample into countries with high versus low foreign institution involvement using the median as the cut-off point. Then the regression is estimated separately in each category. Evidently the learning is much faster if sophisticated foreign institutional investors are actively trading in a country's stock markets.

\section{Conclusion}

Pastor and Veronesi (2003) model an important time-varying dynamics of M/B ratio over the firm's life due to the learning process about the firm's profitability as well as provide the supporting evidence in NYSE firms. In this paper, we provide an out-of-sample evidence that compliments their findings. Specifically, we find the inverse relationship between M/B ratio and the firm's age in the global portfolio of 48 countries. This inverse relationship is statistically significant after controlling for other factors known to determine the market-tobook ratio. Consistent with the convexity concept, the sharp decrease in $\mathrm{M} / \mathrm{B}$ ratio takes place in the earlier years and slow down after about five years. The M/B then stabilizes after ten years. However, different from P\&V result of NYSE stocks, M/B bounces up after year 15 for firms in the developed markets. The inverse relationship between M/B and firm's age is also 
more striking for non-dividend paying firms. Return volatility of stocks in global, developed, and emerging markets also decreases slowly (and steadily) with the firm's age.

We make new discoveries about the speed of learning about firms' profitability in markets that offer different market design and legal framework. Learning is faster in economically developed markets, on fully automated stock exchanges, in countries where prohibitions on insider trading laws are enforced. In developed markets, $\mathrm{M} / \mathrm{B}$ ratio stabilizes after around 10 years. In the emerging markets, $\mathrm{M} / \mathrm{B}$ continue to decrease long after that, reflecting the slower speed of learning. We conjecture that the inferior transparency or financial disclosure in emerging market may block the learning process to some extent. This leads to the next important question. Does the learning process, particularly in emerging markets, improve after market restructuring? Although we do not find the direct evidence that $\mathrm{M} / \mathrm{B}$ ratio stabilizes faster after the improvement in market design or the enforcement of insider trading law, the inverse relation between $\mathrm{M} / \mathrm{B}$ and the firm's age (or the learning process) seems to be less noisy after such treatments, especially for emerging markets. Interestingly, the actual enforcement prohibition against insider law trading seems to have a strong impact in developed markets.

Future research can explore additional determinants of the speed of learning. In the international context, Chiyachantana et al (2004) show that global institutional traders are increasingly becoming active participants in international stock markets. Their involvement and sophisticated research can increase the speed of learning. In conclusion, the learning process about firms' profitability has important implications for stock valuation in countries around the world. The results in this paper implore that asset pricing models include the learning curve as an important factor. 


\section{References}

Bekaert, Geert, and Campbell R. Harvey, 1995, Time-varying world market integration, Journal of Finance 50, 403-444.

Bekaert, Geert, and Campbell Harvey, 2000, Foreign speculators and emerging equity markets, Journal of Finance 55, 565-613.

Bhattacharya, Utpal, and Hazem Daouk, 2002, The world price of insider trading, Journal of Finance 57, 75-108.

Chan, Kalok., 1988, On the contrarian investment strategy, Journal of Business, 61, 147-164.

Charoenrook, A. and H. Daouk, 2003, The world price of short selling, Working paper, Vanderbilt University and Cornell University. http://papers.ssrn.com/sol3/papers.cfm?abstract_id=511622

Chiyachantana, Chiraphol N., Pankaj K. Jain, Christine Jiang, and Robert A. Wood, 2004, International evidence on institutional trading behavior and determinants of price impact, Journal of Finance 59, 865-894.

Compaq Handbook of World Stock, Derivative and Commodity Exchanges, 2001, Financial Publications, UK.

Daniel, Kent and Sheridan Titman, 1997. Evidence on the characteristics of cross sectional variation in stock returns. Journal of Finance 52, 1-33.

Fama, Eugene F. and Kenneth French, 1992. The cross-section of expected stock returns, Journal of Finance 47, 427-465. 
Fama, Eugene F. and Kenneth French, 1993. Common risk factors in the returns on bonds and stocks, Journal of Financial Economics 33, 3-56.

Fama, Eugene F. and Kenneth French, 1995. Size and book-to-market factors in earnings and returns. The Journal of Finance 50, 131-155.

Griffin, John M. and Andrew G. Karolyi, 1998, Another Look at the Role of the Industrial Structure of Markets for International Diversification Strategies, Journal of Financial Economics 50, 351- 373.

Henry, Peter B., 2000, Stock market liberalization, economic reform, and emerging market equity prices, Journal of Finance 55, 529-564.

Jain, Pankaj K., 2004, Financial market design and equity premium, Floor versus electronic trading, Forthcoming, Journal of Finance.

Jones, Steven L., 1993, Another look at time-varying risk and return in a long-horizon contrarian investment strategy, Journal of Financial Economics 33,119-144.

Lakonishok, Josef, Andrei Shleifer, and Robert W. Vishny, 1992, Contrarian investment, extrapolation, and risk, Journal of Finance 49, 1541-1578.

Pastor, Lubos, and Pietro Veronesi, 2003, Stock Valuation and Learning about Profitability, Journal of Finance 58, 1749-1789.

Shefrin, Hersh and Meir Statman, 1995, Making Sense of Beta, Size, and Book-to-market, Journal of Portfolio Management 21, 26-34.

World Federation of Exchanges' (formerly known as the International Federation of Stock Exchanges - FIBV) archives at www.fibv.com. 


\section{Table I Sample Composition}

\begin{tabular}{|c|c|c|c|}
\hline Country & \# of companies & $\begin{array}{l}\text { Market design } \\
\text { improvement } \\
\text { through full } \\
\text { automation and } \\
\text { transparency of the } \\
\text { trading process } \\
\end{array}$ & $\begin{array}{l}\text { Insider trading law } \\
\text { enforcement }\end{array}$ \\
\hline \multicolumn{4}{|c|}{ Panel A: Developed markets } \\
\hline Australia & 1,502 & 1987 & 1996 \\
\hline Austria & 144 & 1996 & No \\
\hline Belgium & 178 & 1996 & 1994 \\
\hline Canada & 1,431 & 1977 & 1976 \\
\hline Denmark & 241 & 1988 & 1996 \\
\hline Finland & 191 & 1988 & 1993 \\
\hline France & 1,038 & 1986 & 1975 \\
\hline Germany & 992 & 1991 & 1995 \\
\hline Hong Kong & 1,059 & 1986 & 1994 \\
\hline Ireland & 51 & 2000 & No \\
\hline Italy & 415 & 1994 & 1996 \\
\hline Japan & 2,552 & 1982 & 1990 \\
\hline Luxembourg & 28 & 1991 & No \\
\hline New Zealand & 34 & 1994 & 1994 \\
\hline Norway & 387 & 1991 & No \\
\hline Portugal & 127 & 1988 & 1990 \\
\hline Singapore & 591 & 1991 & No \\
\hline Spain & 155 & 1989 & 1978 \\
\hline Sweden & 535 & 1989 & 1998 \\
\hline Switzerland & 476 & 1989 & 1990 \\
\hline UK & 2,764 & 1996 & 1995 \\
\hline USA & 2,048 & 1997 & 1981 \\
\hline Total Developed & 16,939 & & \\
\hline \multicolumn{4}{|c|}{ Panel B: Emerging markets } \\
\hline Argentina & 69 & 1995 & 1995 \\
\hline Brazil & 510 & 1990 & 1978 \\
\hline Chile & 183 & 1989 & 1996 \\
\hline China & 1,376 & 1990 & No \\
\hline Colombia & 1,035 & 1996 & No \\
\hline Czech Rep. & 30 & 1998 & 1993 \\
\hline Greece & 380 & 1992 & 1996 \\
\hline Hungary & 36 & 1998 & 1995 \\
\hline India & 342 & 1995 & 1998 \\
\hline Indonesia & 320 & 1995 & 1996 \\
\hline Israel & 98 & 1997 & 1989 \\
\hline Korea (South) & 772 & 1988 & 1988 \\
\hline Malaysia & 897 & 1992 & 1996 \\
\hline Mexico & 124 & 1996 & No \\
\hline Morocco & 14 & 1997 & No \\
\hline Pakistan & 76 & 1997 & No \\
\hline Peru & 82 & 1995 & 1994 \\
\hline Philippines & 248 & 1993 & No \\
\hline Poland & 80 & 1996 & 1993 \\
\hline
\end{tabular}


Russia

South Africa

Sri Lanka

Taiwan

Thailand

Turkey

Venezuala

Total Emerging Markets

Grand Total
1994

1996

1997

1985

1991

1993

1992
1994

No

1996

1989

1993

1996

No

8692

25631 
Table 2. FIRM AGE AND MARKET TO BOOK RATIO IN EACH COUNTRY

\begin{tabular}{|c|c|c|c|c|c|c|c|c|c|c|c|c|c|c|c|c|c|c|c|c|}
\hline Age & 1 & 2 & 3 & 4 & 5 & 6 & 7 & 8 & 9 & 10 & 11 & 12 & 13 & 14 & 15 & 16 & 17 & 18 & 19 & 20 \\
\hline ALL & 1.94 & 1.77 & 1.63 & 1.58 & 1.46 & 1.45 & 1.43 & 1.38 & 1.30 & 1.31 & 1.26 & 1.25 & 1.23 & 1.26 & 1.27 & 1.34 & 1.50 & 1.60 & 1.61 & 1.59 \\
\hline \multicolumn{21}{|c|}{ Panel A: Developed markets } \\
\hline Australia & 1.68 & 1.55 & 1.38 & 1.40 & 1.20 & 1.48 & 1.43 & 1.56 & 1.36 & 1.33 & 1.29 & 1.25 & 1.28 & 1.25 & 1.49 & 1.42 & 1.31 & 1.45 & 1.23 & 1.44 \\
\hline Austria & 1.49 & 1.31 & 1.12 & 1.23 & 1.30 & 1.27 & 0.98 & 1.03 & 0.98 & 0.97 & 0.98 & 0.92 & 1.12 & 1.28 & 1.28 & 1.26 & 1.51 & 2.06 & 2.76 & 2.43 \\
\hline Belgium & 1.62 & 1.30 & 1.18 & 1.24 & 1.15 & 1.18 & 1.05 & 1.18 & 0.97 & 1.03 & 1.18 & 1.25 & 1.28 & 1.20 & 1.22 & 1.07 & 1.26 & 1.28 & 1.18 & 1.11 \\
\hline Canada & 1.54 & 1.56 & 1.49 & 1.55 & 1.50 & 1.50 & 1.61 & 1.71 & 1.60 & 1.56 & 1.54 & 1.47 & 1.49 & 1.48 & 1.34 & 1.42 & 1.50 & 1.48 & 1.44 & 1.43 \\
\hline Denmark & 1.22 & 1.28 & 1.07 & 1.13 & 0.99 & 1.14 & 1.08 & 1.01 & 0.96 & 0.99 & 0.90 & 0.91 & 0.92 & 0.84 & 0.87 & 1.22 & 1.595 & 1.78 & 1.78 & 1.80 \\
\hline Finland & 1.50 & 1.23 & 1.22 & 1.31 & 1.35 & 1.33 & 1.3 & 1.22 & 1.22 & 1.39 & 1.32 & 1.37 & 1.17 & 1.28 & 1.31 & 1.60 & 1.35 & & & \\
\hline France & 2.29 & 1.90 & 1.60 & 1.40 & 1.40 & 1.30 & 1.19 & 1.09 & 1.16 & 1.23 & 1.12 & 1.2 & 1.20 & 1.18 & 1.39 & 1.43 & 1.68 & 1.49 & 1.20 & 1.27 \\
\hline Germany & 2.37 & 1.95 & 1.55 & 1.32 & 1.33 & 1.69 & 1.90 & 2.10 & 2.11 & 1.86 & 1.73 & 1.86 & 1.98 & 2.05 & 1.84 & 1.89 & 1.46 & 1.60 & 1.75 & 1.71 \\
\hline Hong Kong & 1.71 & 1.40 & 1.20 & 1.08 & 0.90 & 0.87 & 0.87 & 0.75 & 0.81 & 0.81 & 0.8 & 0.75 & 0.7 & 0.68 & 0.66 & 0.72 & 0.93 & 0.74 & 0.69 & 0.79 \\
\hline Ireland & 1.81 & 1.71 & 1.55 & 1.61 & 1.59 & 1.64 & 1.58 & 1.87 & 1.79 & 1.88 & 1.42 & 1.72 & 1.39 & 1.16 & 1.20 & 1.27 & 1.00 & 1.02 & 1.23 & 1.14 \\
\hline Italy & 1.60 & 1.51 & 1.40 & 1.39 & 1.15 & 1.05 & 0.94 & 0.99 & 1.00 & 0.91 & 0.92 & 1.23 & 1.31 & 1.45 & 1.57 & 1.36 & 1.42 & 1.52 & 1.00 & 0.77 \\
\hline Japan & 2.42 & 2.27 & 1.98 & 1.79 & 1.53 & 1.48 & 1.54 & 1.40 & 1.37 & 1.17 & 1.14 & 1.29 & 1.30 & 1.39 & 1.50 & 1.88 & 3.18 & 4.10 & 2.36 & 2.30 \\
\hline Luxemboug & 0.87 & 1.40 & 1.26 & 1.19 & 1.44 & 1.88 & 1.81 & 1.34 & 1.05 & 0.90 & 0.83 & 1.02 & 0.36 & & & & & & & \\
\hline New Zealand & 1.36 & 1.22 & 1.07 & 1.02 & 1.02 & 1.03 & 1.04 & 1.31 & 1.35 & 1.30 & 1.24 & 1.24 & 1.10 & 1.29 & 1.15 & 1.14 & 1.24 & 1.24 & & \\
\hline Norway & 1.50 & 1.30 & 1.30 & 1.26 & 1.32 & 1.31 & 1.28 & 1.29 & 1.38 & 1.25 & 1.21 & 1.30 & 1.18 & 1.21 & 1.17 & 1.12 & 1.26 & 1.35 & 1.25 & 1.37 \\
\hline Portugal & 1.84 & 1.76 & 1.63 & 1.51 & 1.35 & 1.30 & 1.28 & 1.00 & 1.09 & 1.20 & 1.28 & 1.35 & 1.08 & 1.07 & 1.17 & 1.04 & 2.35 & & & \\
\hline Singapore & 2.02 & 2.01 & 1.72 & 1.80 & 1.71 & 1.36 & 1.52 & 1.42 & 1.44 & 1.30 & 1.27 & 1.47 & 1.32 & 1.17 & 1.24 & 1.14 & 1.09 & 1.29 & 1.04 & 0.98 \\
\hline
\end{tabular}




\begin{tabular}{|c|c|c|c|c|c|c|c|c|c|c|c|c|c|c|c|c|c|c|c|c|}
\hline South Africa & 2.31 & 2.22 & 1.61 & 1.19 & 1.25 & 1.32 & 1.25 & 1.44 & 1.03 & 1.16 & 1.01 & 0.98 & 1.05 & 1.22 & 1.82 & 1.75 & 1.77 & 1.68 & 1.24 & 1.04 \\
\hline Spain & 1.83 & 1.66 & 1.55 & 1.30 & 1.37 & 1.30 & 1.43 & 1.41 & 1.48 & 1.66 & 1.71 & 1.96 & 1.66 & 1.63 & 1.67 & 1.62 & 1.89 & 1.77 & & \\
\hline Sweden & 2.07 & 1.99 & 1.90 & 1.70 & 1.45 & 1.55 & 1.59 & 1.55 & 1.49 & 1.61 & 1.53 & 1.68 & 1.67 & 1.66 & 1.71 & 1.94 & 1.78 & 1.94 & 1.92 & 1.92 \\
\hline Switzerland & 1.50 & 1.31 & 1.17 & 1.19 & 1.11 & 1.07 & 1.16 & 1.11 & 1.11 & 1.04 & 1.12 & 1.19 & 1.22 & 1.36 & 1.35 & 1.29 & 1.30 & 1.38 & 1.30 & 1.13 \\
\hline UK & 2.61 & 2.22 & 1.97 & 1.83 & 1.79 & 1.75 & 1.70 & 1.68 & 1.66 & 1.76 & 1.75 & 1.73 & 1.22 & 1.24 & 1.20 & 1.23 & 1.22 & 1.35 & 1.55 & 1.49 \\
\hline USA & 1.69 & 1.74 & 1.74 & 1.75 & 1.73 & 1.65 & 1.60 & 1.50 & 1.32 & 1.49 & 1.56 & 1.47 & 1.60 & 1.65 & 1.47 & 1.6 & 1.69 & 1.51 & 1.71 & 1.71 \\
\hline TOTAL & 1.94 & 1.76 & 1.63 & 1.56 & 1.44 & 1.43 & 1.44 & 1.39 & 1.33 & 1.33 & 1.31 & 1.35 & 1.36 & 1.38 & 1.36 & 1.44 & 1.64 & 1.69 & 1.68 & 1.66 \\
\hline
\end{tabular}

\section{Panel B: Emerging markets}

\begin{tabular}{|c|c|c|c|c|c|c|c|c|c|c|c|c|c|c|c|c|c|c|c|c|}
\hline Argentina & 1.22 & 1.00 & 1.04 & 1.34 & 1.19 & 0.84 & 0.78 & 0.58 & 0.4 & 0.65 & 0.78 & 0.96 & 0.94 & 0.56 & 0.84 & 0.94 & & & & \\
\hline Brazil & 0.83 & 1.28 & 0.82 & 0.75 & 0.92 & 0.97 & 0.95 & 0.93 & 0.66 & 0.585 & 0.62 & 0.64 & 0.58 & 0.77 & & & & & & \\
\hline Chile & 1.18 & 1.12 & 1.63 & 1.43 & 1.28 & 1.44 & 1.33 & 1.08 & 0.97 & 0.74 & 0.94 & 0.97 & 0.91 & 0.96 & 1.30 & & & & & \\
\hline China & 3.33 & 2.70 & 2.50 & 2.75 & 2.76 & 2.56 & 2.58 & 3.10 & 3.31 & 3.01 & 2.63 & 3.27 & 2.04 & 1.21 & 1.19 & 1.19 & 1.23 & 1.69 & 1.69 & 2.39 \\
\hline Colombia & 1.09 & 0.72 & 0.74 & 0.65 & 0.43 & 0.53 & 0.56 & 0.51 & 0.48 & 0.545 & 0.59 & 0.91 & & & & & & & & \\
\hline Czech Rep. & 0.77 & 1.20 & 1.01 & 0.66 & 0.74 & 0.5 & 0.45 & 0.54 & 0.82 & 0.42 & 0.66 & & & & & & & & & \\
\hline Greece & 2.53 & 2.23 & 1.89 & 1.91 & 1.42 & 1.53 & 1.35 & 1.25 & 1.22 & 1.98 & 2.06 & 2.84 & 1.69 & 1.51 & 1.24 & 1.42 & & & & \\
\hline Hungary & 1.49 & 1.06 & 1.20 & 1.10 & 0.96 & 0.9 & 0.94 & 0.94 & 0.78 & 0.74 & 0.46 & 0.35 & 0.29 & & & & & & & \\
\hline India & 1.84 & 1.85 & 2.01 & 2.16 & 2.12 & 2.23 & 1.54 & 1.34 & 1.04 & 0.89 & 1.03 & 0.87 & 0.69 & 1.04 & 1.79 & 2.72 & 1.56 & 0.95 & 1.13 & 0.88 \\
\hline Indonesia & 1.69 & 1.28 & 1.18 & 1.25 & 0.93 & 0.88 & 0.83 & 0.79 & 0.75 & 1.15 & 0.72 & 0.56 & 0.56 & 0.85 & & & & & & \\
\hline Israel & 1.94 & 1.84 & 2.31 & 1.86 & 1.51 & 1.16 & 1.54 & 1.92 & 1.61 & 1.83 & 1.49 & 1.55 & 1.18 & 1.6 & 1.51 & 1.26 & 1.08 & 1.31 & & \\
\hline Korea & 1.45 & 1.26 & 1.06 & 0.87 & 0.83 & 0.91 & 0.78 & 0.69 & 0.61 & 0.66 & 0.65 & 0.57 & 0.53 & 0.38 & 0.40 & 0.38 & 0.28 & 0.40 & 0.34 & 0.38 \\
\hline
\end{tabular}




\begin{tabular}{|c|c|c|c|c|c|c|c|c|c|c|c|c|c|c|c|c|c|c|c|c|}
\hline Malaysia & 1.47 & 1.44 & 1.42 & 1.50 & 1.28 & 1.17 & 1.12 & 1.29 & 1.41 & 1.40 & 1.50 & 0.80 & 0.86 & 1.17 & 0.91 & 0.92 & 0.77 & 0.97 & 1.15 & 1.07 \\
\hline Mexico & 1.23 & 1.49 & 1.25 & 1.19 & 1.13 & 1.19 & 1.11 & 0.97 & 1.06 & 1.00 & 1.07 & 1.08 & 1.15 & 0.97 & 0.86 & 0.85 & & & & \\
\hline Morocco & 2.98 & 2.07 & 2.40 & 2.01 & 2.03 & 2.31 & 2.10 & 1.74 & 1.62 & 1.48 & 1.97 & & & & & & & & & \\
\hline Pakistan & 1.81 & 2.61 & 1.96 & 1.18 & 0.93 & 1.00 & 0.78 & 0.83 & 1.01 & 0.92 & 1.10 & 1.61 & 1.12 & 1.71 & & & & & & \\
\hline Peru & 1.31 & 1.08 & 1.18 & 1.10 & 1.06 & 0.95 & 0.84 & 0.81 & 0.75 & 0.77 & 0.66 & 0.56 & 0.53 & & & & & & & \\
\hline Philippines & 1.86 & 1.75 & 1.39 & 1.21 & 1.29 & 1.24 & 1.14 & 1.02 & 0.81 & 0.8 & 0.76 & 0.91 & 0.72 & 0.63 & 0.69 & 0.95 & 1.24 & 5.00 & 3.96 & 3.02 \\
\hline Poland & 1.13 & 1.10 & 1.12 & 1.20 & 1.12 & 1.33 & 1.28 & 1.31 & 1.04 & 1.00 & 1.00 & 0.35 & 0.83 & & & & & & & \\
\hline Russia & 0.39 & 0.30 & 0.62 & 0.31 & 0.43 & 0.37 & 0.36 & 0.30 & 0.65 & 0.19 & & & & & & & & & & \\
\hline Sri Lanka & 1.65 & 2.16 & 0.98 & 1.16 & 1.49 & 0.94 & 1.89 & 1.72 & 1.07 & 1.03 & 1.12 & 0.98 & 0.92 & 0.69 & 0.92 & 0.94 & 1.02 & & & \\
\hline Taiwan & 2.46 & 2.31 & 1.96 & 1.67 & 1.61 & 1.67 & 1.59 & 1.46 & 1.43 & 1.30 & 1.07 & 0.8 & 0.72 & 0.74 & 0.80 & 0.78 & 0.90 & & & \\
\hline Thailand & 2.64 & 2.33 & 2.08 & 1.61 & 1.57 & 1.52 & 1.28 & 1.13 & 1.01 & 1.06 & 0.84 & 0.92 & 0.94 & 0.85 & 0.93 & 1.04 & 1.18 & & & \\
\hline Turkey & 1.35 & 1.91 & 1.34 & 1.58 & 1.25 & 1.43 & 1.37 & 1.29 & 1.40 & 1.85 & 1.17 & 2.15 & 1.18 & 1.29 & 0.88 & 1.44 & & & & \\
\hline Venezuela & 0.21 & 0.49 & 0.41 & 0.37 & 0.85 & 0.42 & 0.53 & 0.58 & 0.22 & 0.27 & 0.26 & 0.13 & 0.12 & 0.32 & & & & & & \\
\hline TOTAL & 1.96 & 1.80 & 1.65 & 1.63 & 1.51 & 1.52 & 1.41 & 1.36 & 1.21 & 1.22 & 1.11 & 0.91 & 0.80 & 0.84 & 0.86 & 0.80 & 0.71 & 0.72 & 0.51 & 0.63 \\
\hline
\end{tabular}




\section{Table 3 Regression analysis on M/B ratio and the firm's age for Global portfolio}

The following cross sectional regression is estimated separately for each year: $\log (\mathrm{M} / \mathrm{B})_{\mathrm{i}}=\mathrm{a}+$ b.AGE $\mathrm{i}_{\mathrm{i}}+$ c.DD $_{\mathrm{i}}+$ d.LEV $_{\mathrm{i}}+$ e.SIZE $\mathrm{E}_{\mathrm{i}}+$ f.ROE $\mathrm{i}_{\mathrm{i}}+$ g.ROE $(1)_{i}+h \cdot \operatorname{ROE}(2)_{i}+\mathrm{i} \cdot \operatorname{ROE}(3)_{\mathrm{i}}+\mathrm{j} \cdot \operatorname{RET}(1)_{\mathrm{i}}+\mathrm{k} \cdot \operatorname{RET}(2)_{\mathrm{i}}+1 \cdot \operatorname{RET}(3)_{\mathrm{i}}$ where $(\mathrm{i}=1-\mathrm{N}, \mathrm{N}$ is the \# of firms in each year $\mathrm{t})$. AGE is defined as $-1 /(1+$ Firm's Age) following Pastor and Veronesi (2003). DD is the dividend dummy with value 1 for dividend paying firm and 0 otherwise. LEV is the debt ratio. SIZE is the natural log of the firm's totol asset. ROE is the return on equity and regressed up to three years following year t. RET is future annual stock return up to three years from current period. All variables of firms in each country are measured in its own currency. The number of observations ranges from 1,109 to 10,103 in year 1982 and 2000 respectively. Each regression system is accounted for possible autocorrelation and heteroskedasticity problem. All t-statistics are reported in parentheses.

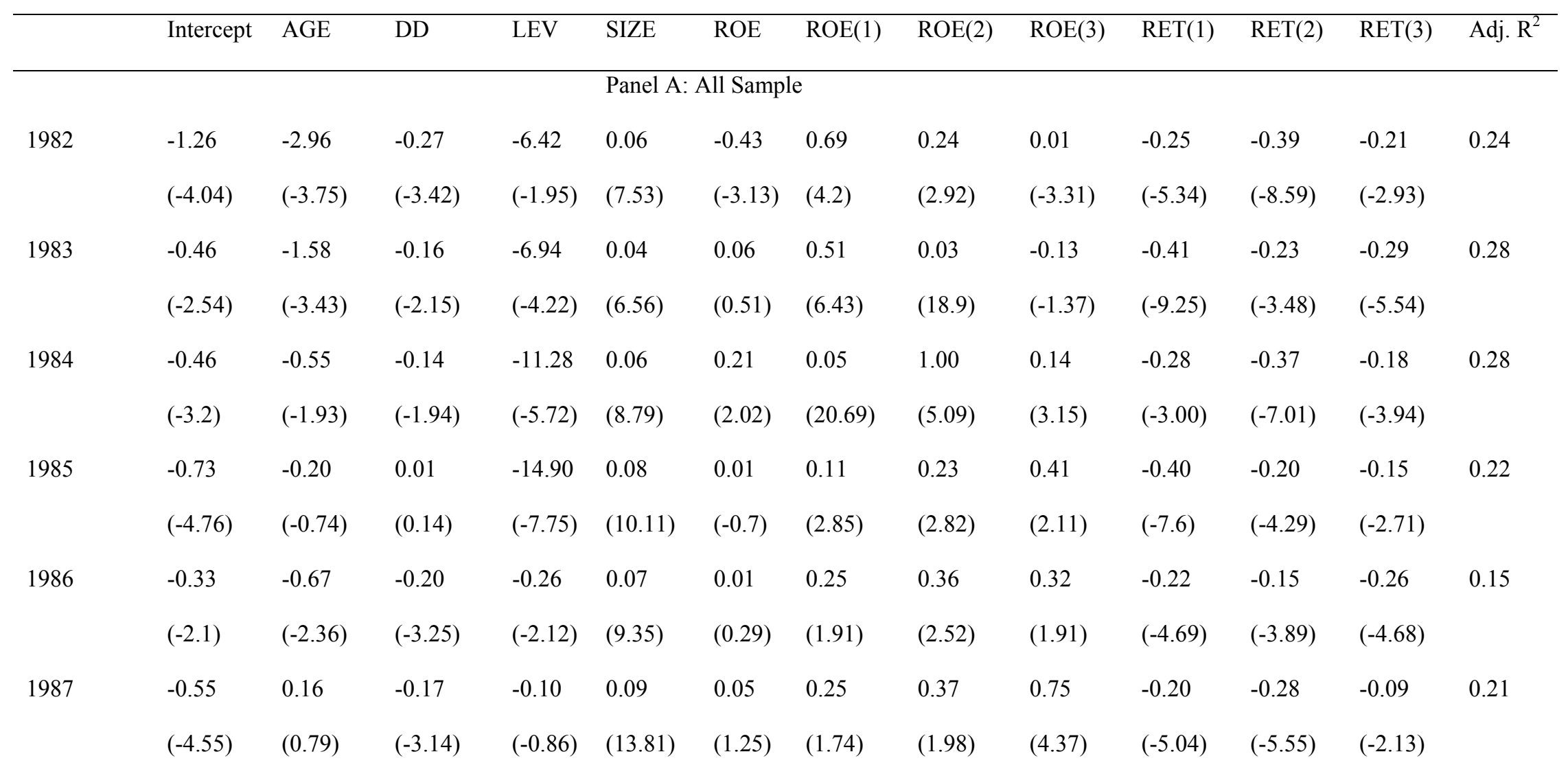




\begin{tabular}{|c|c|c|c|c|c|c|c|c|c|c|c|c|c|}
\hline \multirow[t]{2}{*}{1988} & -0.35 & 0.46 & -0.21 & -0.30 & 0.08 & -0.08 & 0.54 & 0.81 & 0.25 & -0.44 & -0.05 & -0.49 & 0.28 \\
\hline & $(-3.25)$ & $(3.85)$ & $(-4.53)$ & $(-2.66)$ & (12.36) & $(-0.98)$ & $(3.51)$ & $(5.5)$ & (3.24) & $(-7.95)$ & $(-1.53)$ & $(-6.47)$ & \\
\hline \multirow[t]{2}{*}{1989} & -0.19 & 0.38 & -0.25 & -0.22 & 0.07 & 0.34 & 0.21 & 0.09 & 0.25 & -0.08 & -0.50 & -0.11 & 0.21 \\
\hline & $(-1.98)$ & $(3.42)$ & $(-5.13)$ & $(-1.98)$ & (13.28) & $(2.16)$ & $(2.55)$ & (1.49) & $(1.53)$ & $(-4.97)$ & $(-8.48)$ & $(-2.67)$ & \\
\hline \multirow[t]{2}{*}{1990} & 0.00 & 0.21 & -0.38 & -0.38 & 0.07 & 0.03 & -0.04 & 0.83 & 0.30 & -0.59 & -0.18 & -0.33 & 0.31 \\
\hline & $(-0.04)$ & $(2.21)$ & $(-7.13)$ & $(-3.77)$ & $(15.8)$ & $(3.2)$ & $(-0.53)$ & $(4.09)$ & $(2.57)$ & $(-12.95)$ & $(-5.32)$ & $(-6.63)$ & \\
\hline \multirow[t]{2}{*}{1991} & 0.18 & 0.32 & -0.22 & -0.33 & 0.04 & 0.19 & 0.48 & 0.30 & 0.15 & -0.25 & -0.27 & -0.20 & 0.24 \\
\hline & $(2.32)$ & (3.79) & $(-5.03)$ & $(-3.88)$ & (10.37) & (1.49) & $(3.75)$ & $(2.21)$ & $(2.1)$ & $(-6.58)$ & $(-5.51)$ & $(-8.42)$ & \\
\hline \multirow[t]{2}{*}{1992} & 0.13 & 0.14 & -0.12 & -0.20 & 0.04 & 0.25 & 0.12 & 0.47 & 0.03 & -0.30 & -0.17 & -0.20 & 0.16 \\
\hline & $(1.74)$ & $(1.37)$ & $(-3.44)$ & $(-2.34)$ & $(9.38)$ & $(3.04)$ & $(0.89)$ & $(4.08)$ & $(0.88)$ & $(-8.16)$ & $(-6.29)$ & $(-5.6)$ & \\
\hline \multirow[t]{2}{*}{1993} & -0.12 & -0.05 & 0.01 & -0.07 & 0.03 & 0.06 & 0.48 & 0.05 & 0.39 & -0.08 & -0.28 & 0.04 & 0.13 \\
\hline & $(-1.28)$ & $(-0.46)$ & $(0.26)$ & $(-0.82)$ & $(6.86)$ & $(1.03)$ & $(3.55)$ & $(1.36)$ & $(3.25)$ & $(-1.79)$ & $(-7.71)$ & $(1.58)$ & \\
\hline \multirow[t]{2}{*}{1994} & 0.47 & -0.37 & -0.01 & -0.08 & 0.00 & 0.20 & 0.19 & 0.48 & 0.10 & -0.39 & -0.02 & -0.15 & 0.19 \\
\hline & $(6.81)$ & $(-3.82)$ & $(-0.32)$ & $(-0.97)$ & $(0.92)$ & $(2.44)$ & (4.94) & (3.83) & $(2.44)$ & $(-7.12)$ & $(-0.58)$ & $(-5.42)$ & \\
\hline \multirow[t]{2}{*}{1995} & 0.27 & -0.21 & -0.07 & 0.03 & 0.02 & 0.09 & 0.55 & 0.16 & 0.04 & -0.15 & -0.17 & 0.00 & 0.11 \\
\hline & $(3.82)$ & $(-2.33)$ & $(-2.47)$ & $(0.45)$ & $(4.5)$ & $(1.95)$ & $(4.77)$ & (3.99) & (1.97) & $(-5.66)$ & $(-5.3)$ & $(-20.14)$ & \\
\hline \multirow[t]{2}{*}{1996} & 0.39 & -0.03 & -0.08 & -0.01 & 0.01 & 0.02 & 0.44 & 0.13 & 0 & -0.24 & 0.00 & 0.00 & 0.11 \\
\hline & $(5.71)$ & $(-0.3)$ & $(-2.86)$ & $(-0.19)$ & $(2.29)$ & (1.99) & $(9.22)$ & $(2.45)$ & $(-0.73)$ & $(-8.93)$ & $(-19.43)$ & $(-1.88)$ & \\
\hline 1997 & 0.55 & -0.30 & 0.01 & 0.15 & -0.01 & 0.04 & 0.17 & 0 & 0.07 & 0.00 & 0.00 & -0.01 & 0.04 \\
\hline
\end{tabular}




\begin{tabular}{|c|c|c|c|c|c|c|c|c|c|c|c|c|c|}
\hline & (7.87) & $(-3.28)$ & $(0.51)$ & $(2.17)$ & $(-2.49)$ & (1.67) & $(2.44)$ & $(0.71)$ & $(2.02)$ & $(-31.51)$ & $(-1.21)$ & $(-3.27)$ & \\
\hline \multirow[t]{2}{*}{1998} & 1.11 & -0.44 & 0.06 & 0.35 & -0.06 & 0.04 & 0.04 & 0.14 & 0.09 & -0.01 & -0.01 & 0.10 & 0.09 \\
\hline & $(15.96)$ & $(-4.61)$ & $(2.11)$ & $(4.85)$ & $(-15.1)$ & (1.53) & $(3.15)$ & (3.89) & $(2.54)$ & $(-0.87)$ & $(-3.49)$ & $(4.43)$ & \\
\hline \multirow[t]{2}{*}{1999} & 0.77 & -0.55 & 0.17 & 0.32 & -0.05 & 0.01 & 0.14 & 0.12 & 0.07 & -0.04 & 0.00 & 0.00 & 0.07 \\
\hline & (11.94) & $(-6.16)$ & (6.77) & $(4.58)$ & $(-13.76)$ & (1.12) & $(2.5)$ & (2) & (2.04) & $(-4.89)$ & $(0.03)$ & $(-17.11)$ & \\
\hline \multirow[t]{2}{*}{2000} & 0.95 & -1.21 & 0.07 & -0.02 & -0.05 & 0.02 & 0.14 & 0.01 & 0.07 & -0.16 & 0.00 & -0.30 & 0.11 \\
\hline & (14.9) & $(-14.39)$ & (3.39) & $(-0.31)$ & $(-13.9)$ & $(0.93)$ & (1.87) & $(1.22)$ & (1.55) & $(-8.69)$ & $(5.02)$ & $(-9.69)$ & \\
\hline \multirow[t]{2}{*}{2001} & 0.88 & -1.24 & 0.06 & 0.55 & -0.06 & 0.02 & -0.02 & 0.4 & -0.02 & -0.38 & -0.30 & -0.07 & 0.18 \\
\hline & $(10.22)$ & $(-9.04)$ & (1.61) & $(5.08)$ & $(-12.82)$ & $(0.6)$ & $(-2.8)$ & $(3.85)$ & $(-1.6)$ & $(-7.41)$ & $(-7.96)$ & $(-1.72)$ & \\
\hline Avg. coef. & 0.06 & -0.44 & -0.09 & -2.01 & 0.03 & 0.06 & 0.27 & 0.31 & 0.16 & -0.24 & -0.18 & -0.15 & 0.18 \\
\hline t-stat & $(0.45)$ & $(-2.39)$ & $(-2.95)$ & $(-2.06)$ & $(2.22)$ & $(1.65)$ & $(5.49)$ & $(4.83)$ & (3.69) & $(-6.88)$ & $(-5.34)$ & $(-4.44)$ & \\
\hline
\end{tabular}

Panel B: Developed vs Emerging

Developed markets

\begin{tabular}{|c|c|c|c|c|c|c|c|c|c|c|c|c|c|}
\hline Avg.coeff. & 0.06 & -0.40 & -0.12 & -2.02 & 0.03 & 0.04 & 0.28 & 0.33 & 0.18 & -0.26 & -0.19 & -0.16 & 0.20 \\
\hline t-stat & $(0.45)$ & $(-2.25)$ & $(-4.51)$ & $(-2.11)$ & $(2.57)$ & (1.35) & $(6.26)$ & $(5.78)$ & $(4.23)$ & $(-7.83)$ & $(-5.46)$ & $(-4.92)$ & \\
\hline \multicolumn{14}{|c|}{$\underline{\text { Emerging markets }}$} \\
\hline Avg.coeff. & 0.71 & -0.76 & -0.07 & 0.04 & -0.03 & 0.39 & 0.67 & 0.38 & 0.43 & -0.38 & -0.29 & -0.27 & 0.33 \\
\hline t-stat & (3.64) & $(-4.67)$ & $(-0.91)$ & $(-0.35)$ & $(-2.04)$ & $(3.50)$ & $(3.75)$ & $(2.60)$ & $(2.56)$ & $(-4.66)$ & $(-4.05)$ & $(-2.63)$ & \\
\hline
\end{tabular}


Panel C: Shortselling ability

$\underline{\text { Shortselling }=\text { Yes }}$

\begin{tabular}{|c|c|c|c|c|c|c|c|c|c|c|c|c|c|}
\hline Avg.coeff. & 0.05 & -0.45 & -0.13 & -1.98 & 0.03 & 0.06 & 0.27 & 0.32 & 0.08 & -0.26 & -0.19 & -0.16 & 0.20 \\
\hline t-stat & $(0.35)$ & $(-2.36)$ & $(-4.59)$ & $(-2.02)$ & $(2.66)$ & $(1.53)$ & $(5.40)$ & $(5.18)$ & $(4.14)$ & $(-7.39)$ & $(-5.58)$ & $(-4.82)$ & \\
\hline \multicolumn{14}{|c|}{$\underline{\text { Shortselling }=\text { No }}$} \\
\hline Avg.coeff. & 0.64 & -0.62 & 0.03 & -0.32 & -0.04 & 0.25 & 0.61 & 0.49 & 0.23 & -0.24 & -0.26 & -0.24 & 0.29 \\
\hline t-stat & $(4.62)$ & $(-3.70)$ & $(0.54)$ & $(-2.98)$ & $(-4.36)$ & (1.99) & $(4.78)$ & $(4.44)$ & $(2.09)$ & $(-5.94)$ & $(-4.64)$ & $(-4.01)$ & \\
\hline
\end{tabular}

Panel D: Foreign Investing

$\underline{\text { Foreign }=\text { High }}$

\begin{tabular}{|c|c|c|c|c|c|c|c|c|c|c|c|c|c|}
\hline Avg.coeff. & 0.54 & -0.80 & 0.05 & -0.77 & -0.04 & 0.29 & 0.55 & 0.45 & 0.21 & -0.35 & -0.25 & -0.19 & 0.28 \\
\hline t-stat & $(3.95)$ & $(-4.28)$ & (1.49) & $(-1.60)$ & $(-5.67)$ & (3.24) & (3.38) & $(4.35)$ & (3.98) & $(-7.64)$ & $(-5.35)$ & $(-5.24)$ & \\
\hline \multicolumn{14}{|c|}{ Foreign $=$ Low } \\
\hline Avg.coeff. & -0.25 & -0.29 & -0.17 & -4.68 & 0.05 & 0.10 & 0.44 & 0.34 & 0.13 & -0.27 & -0.17 & -0.14 & 0.18 \\
\hline t-stat & $(-1.89)$ & $(-1.74)$ & $(-4.29)$ & $(-1.74)$ & $(4.12)$ & (1.65) & $(5.30)$ & $(3.78)$ & $(1.86)$ & $(-6.26)$ & $(-4.42)$ & $(-3.47)$ & \\
\hline
\end{tabular}

*Foreign investing are categorized based on numbers in the year 2001 (we have applied the regression on 1997 categorization and the grouping are quite in the same line). Please note that there are only 40 countries in the framework. Some important countries unaccounted for include the United States and so on. 


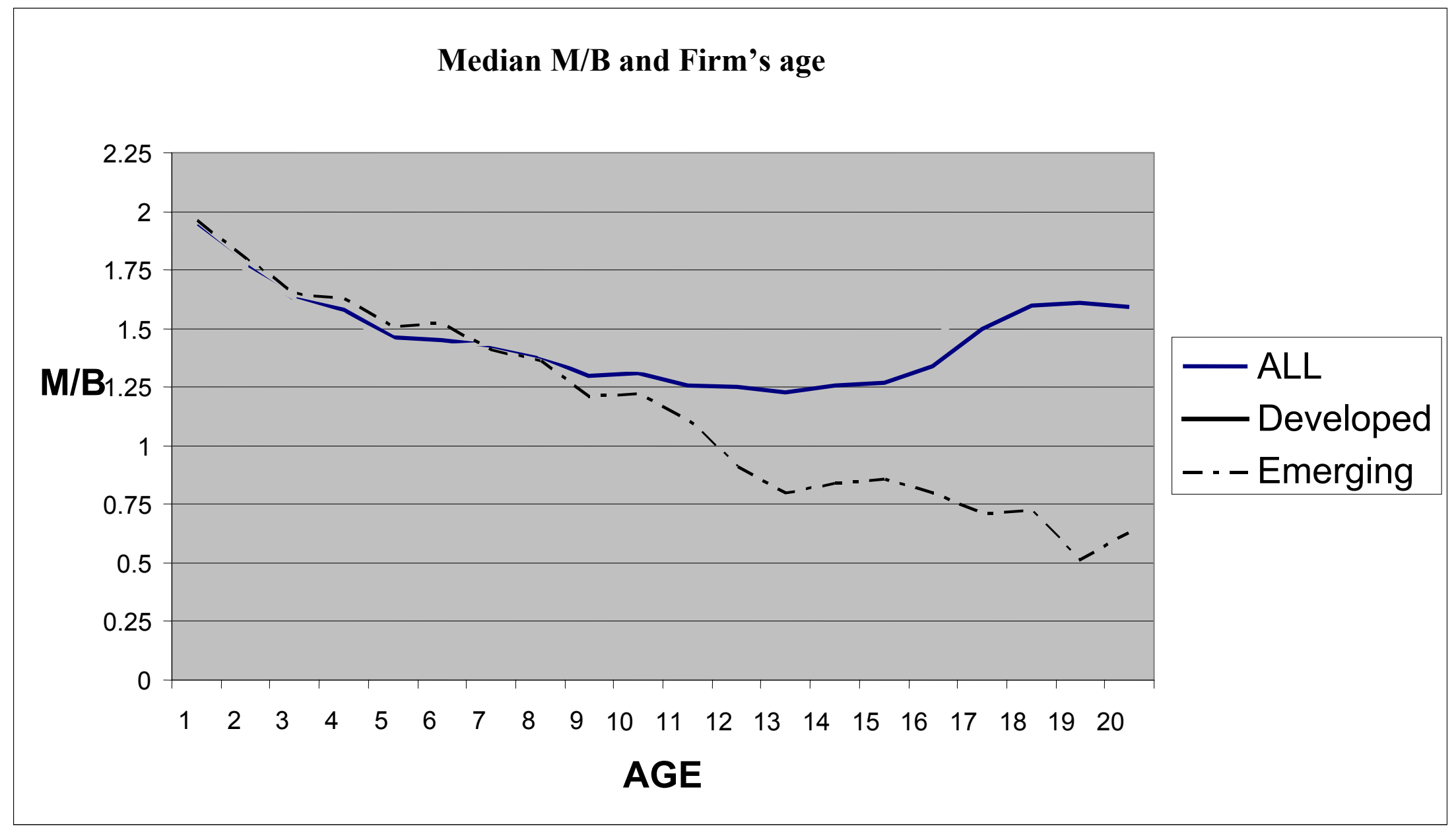

Figure 1a. Firm Age and Median Market to Book Ratio. 


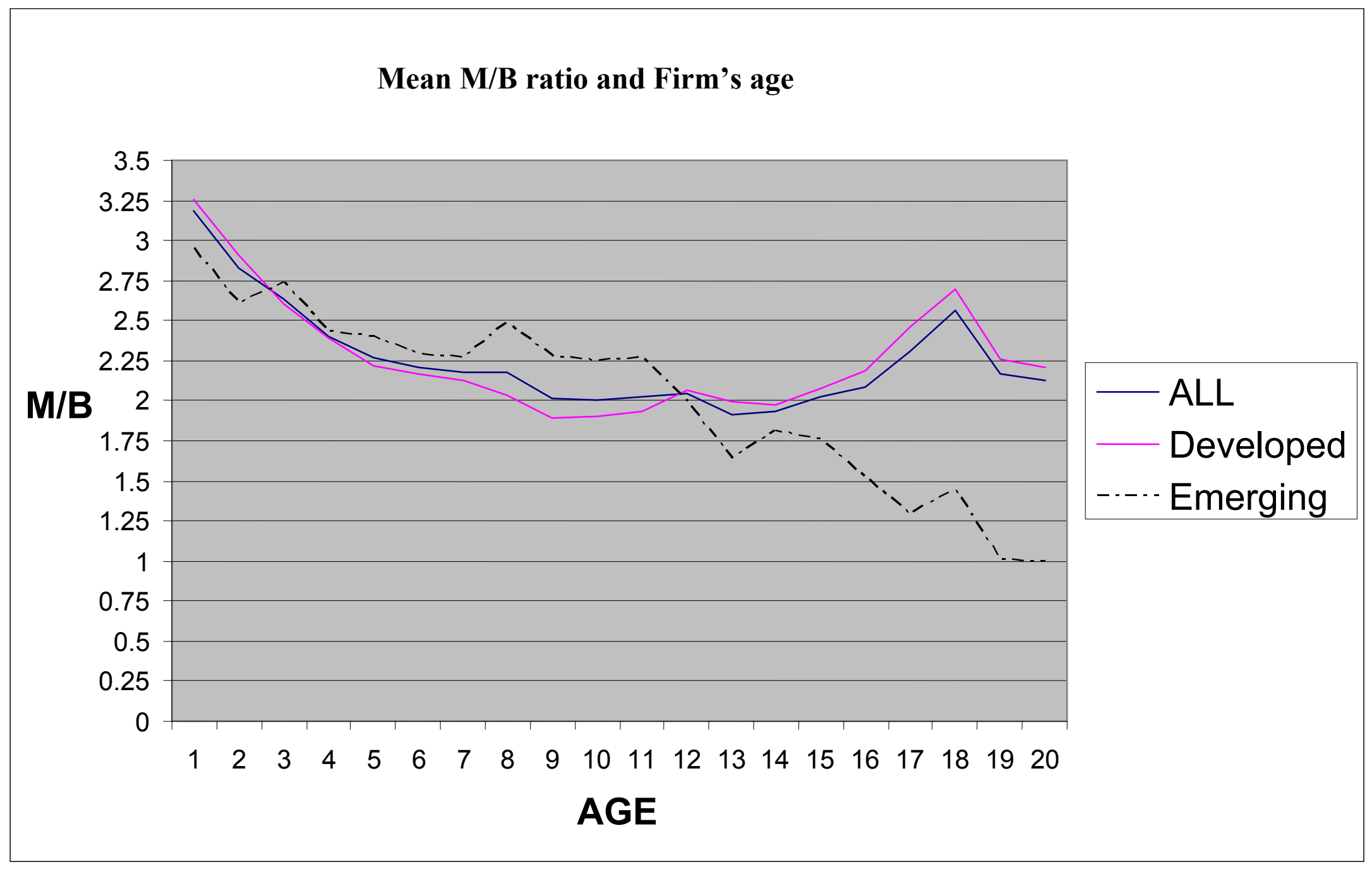

Figure 1b. Firm Age and Mean Market to Book Ratio 


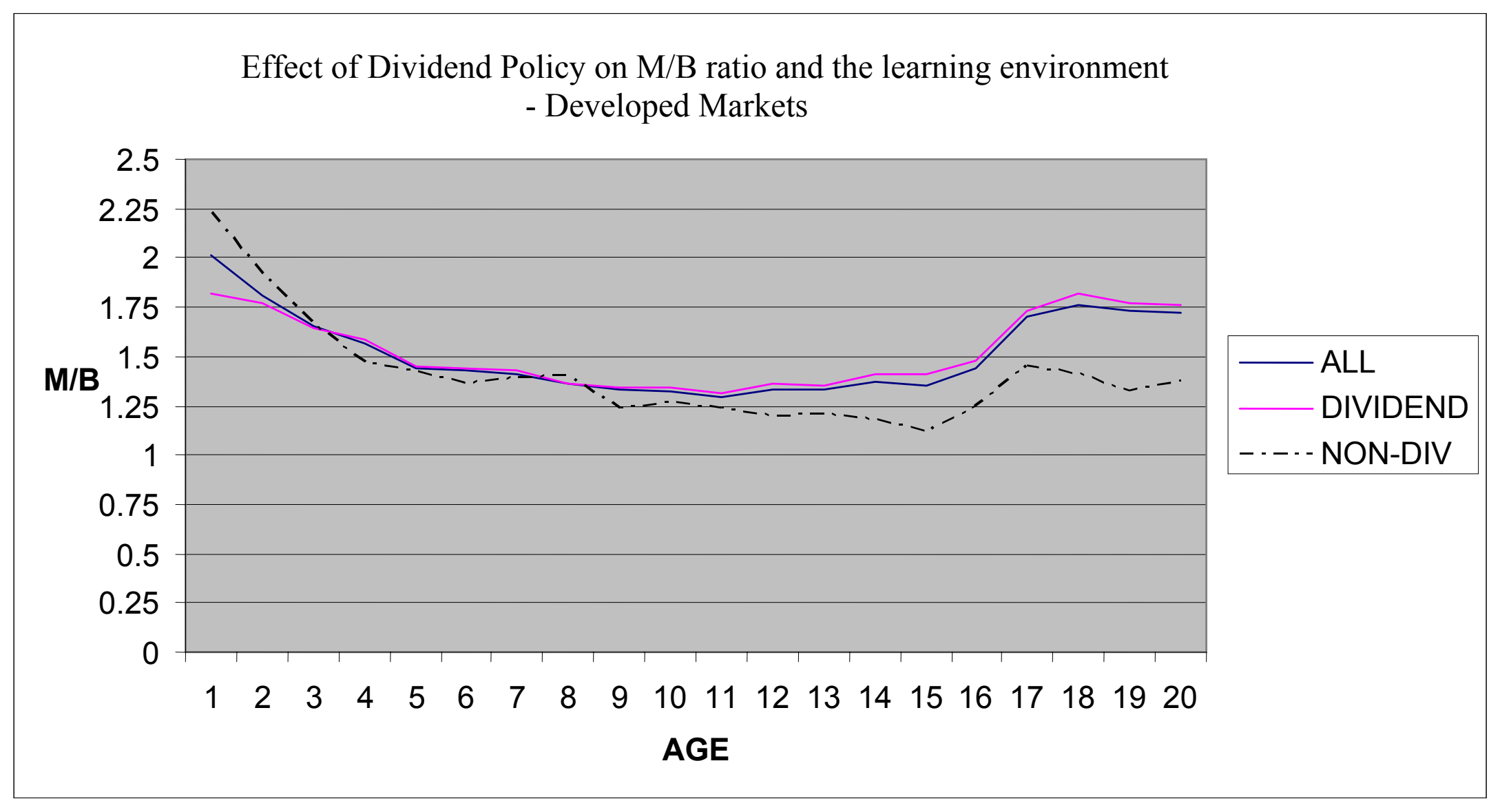

Figure 2a Firm Age and Median M/B Ratio for Dividend Paying firms and non dividend paying firms - Developed markets 


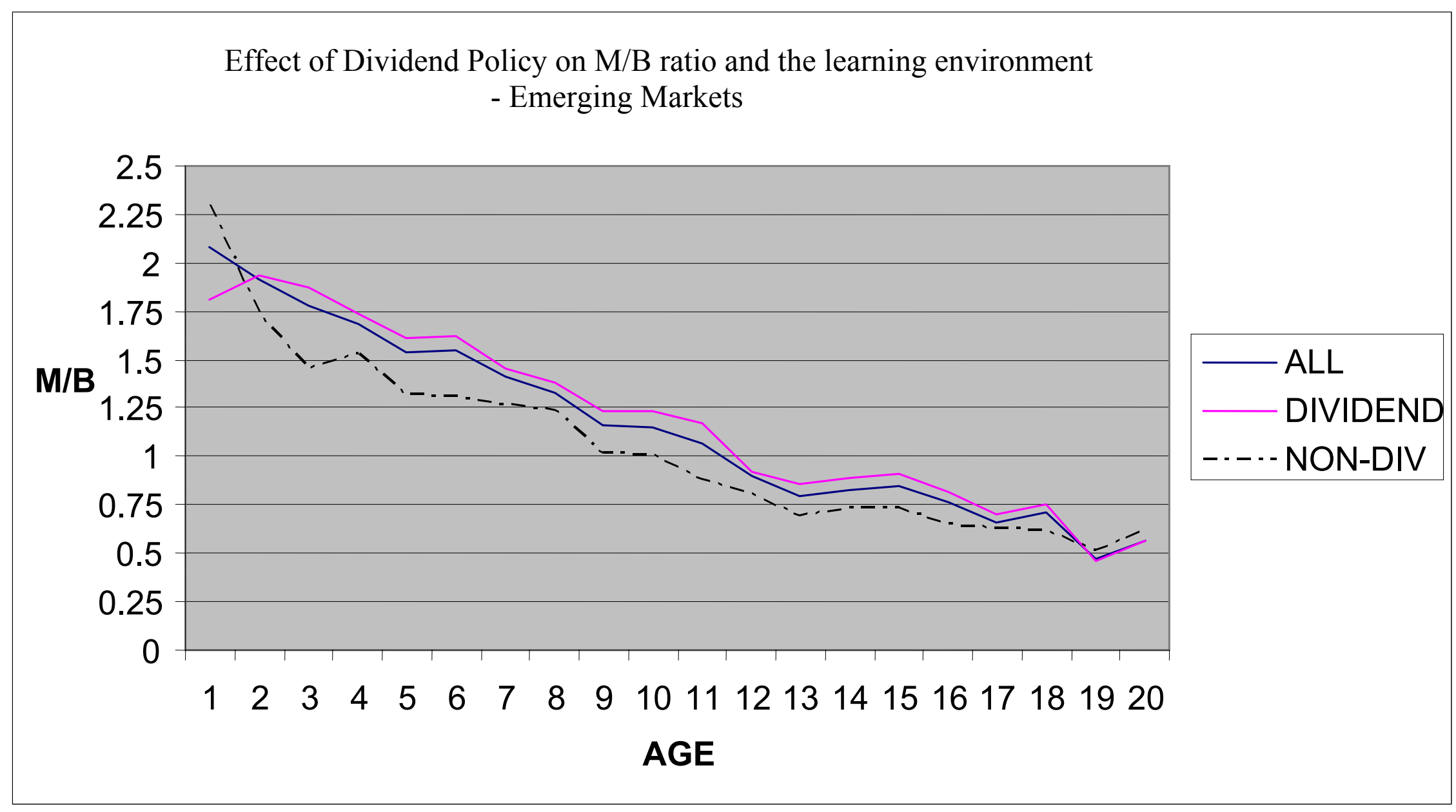

Figure 2b Firm Age and Median M/B Ratio for Dividend Paying firms and non dividend paying firms - Emerging markets 


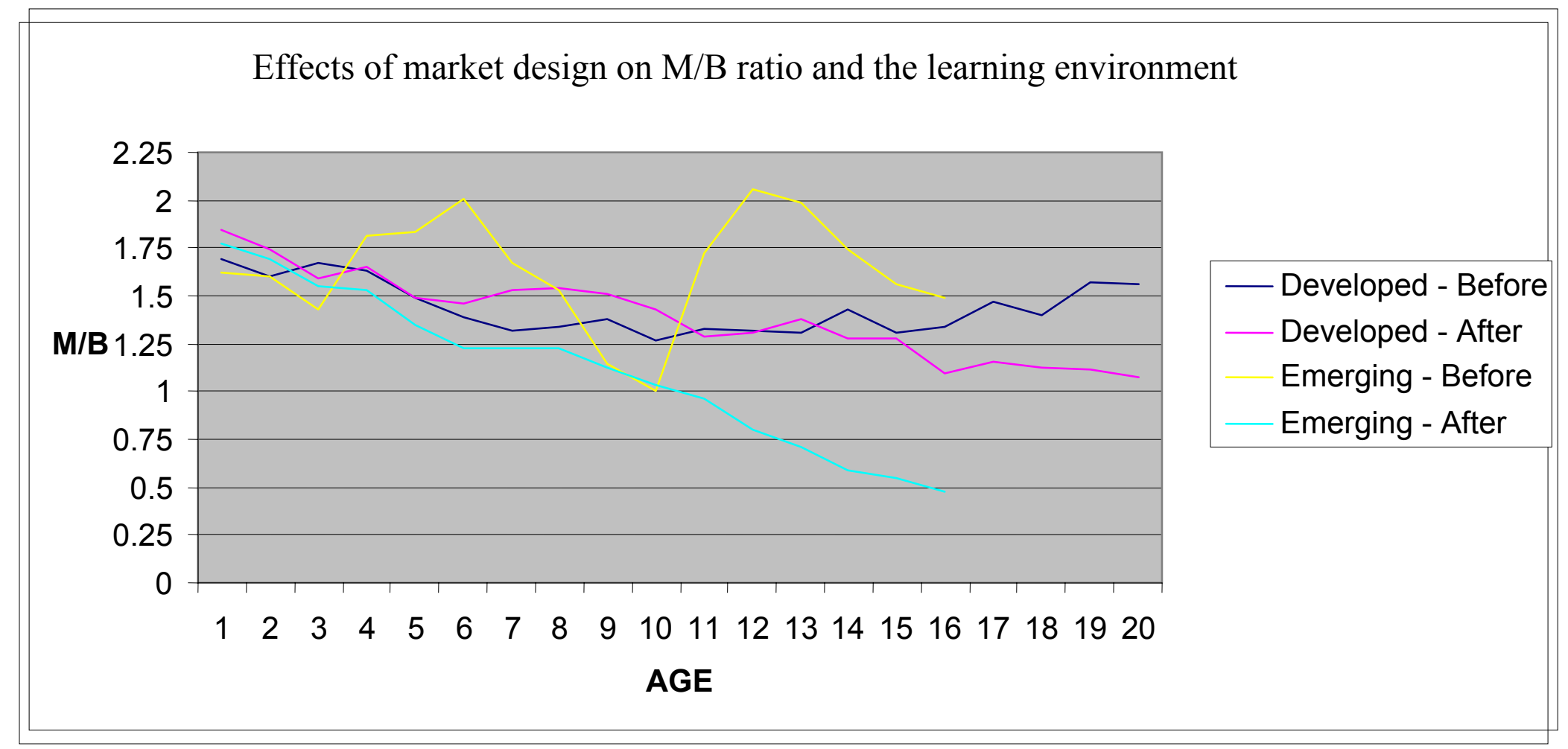

Figure 3(a) M/B ratio vs Age: Before and After improvement in market design though full Automation of Trading process as discussed in Jain (2004) 


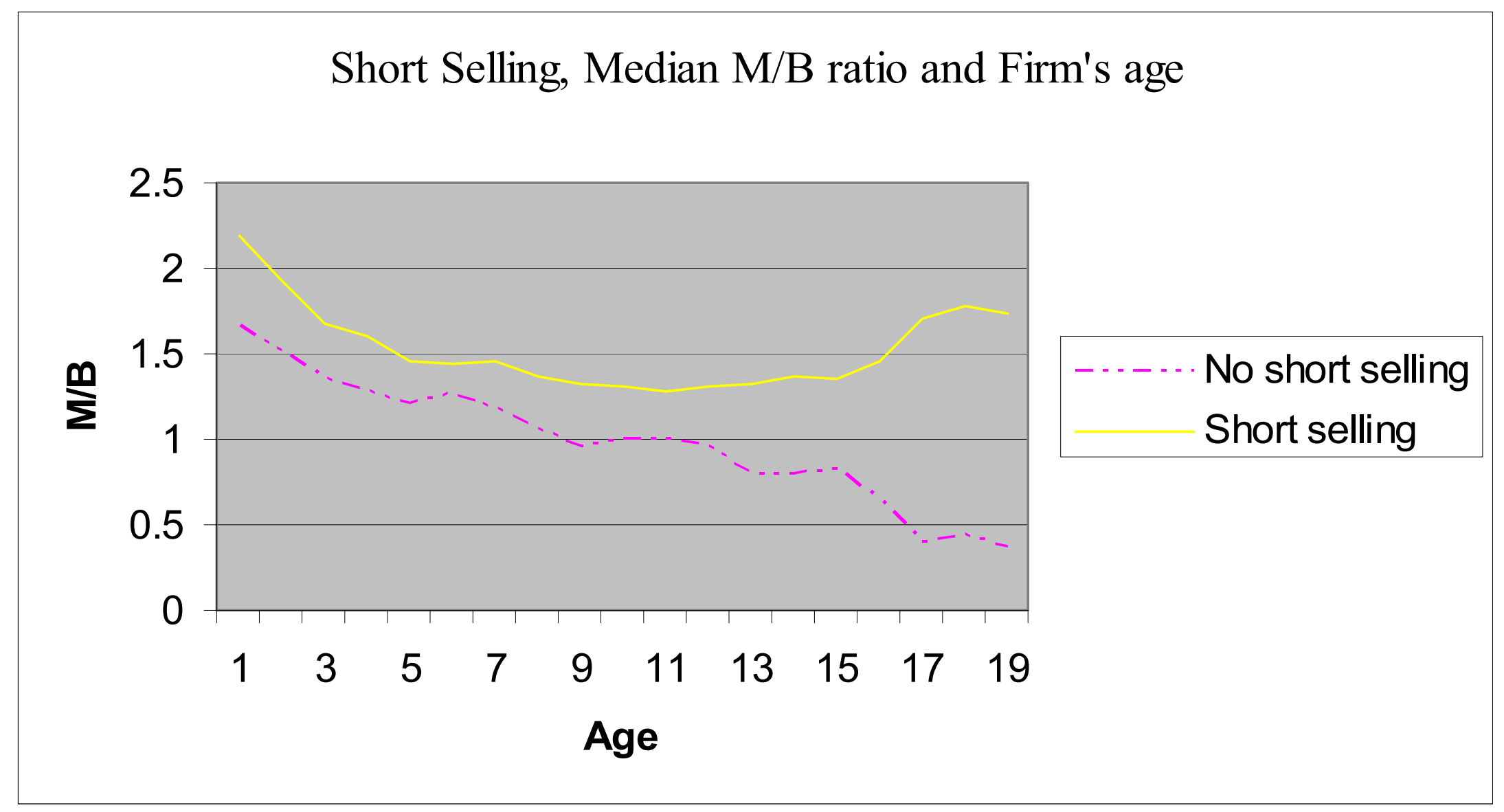

Figure 3 (b): Short Selling and the Learning Environment 


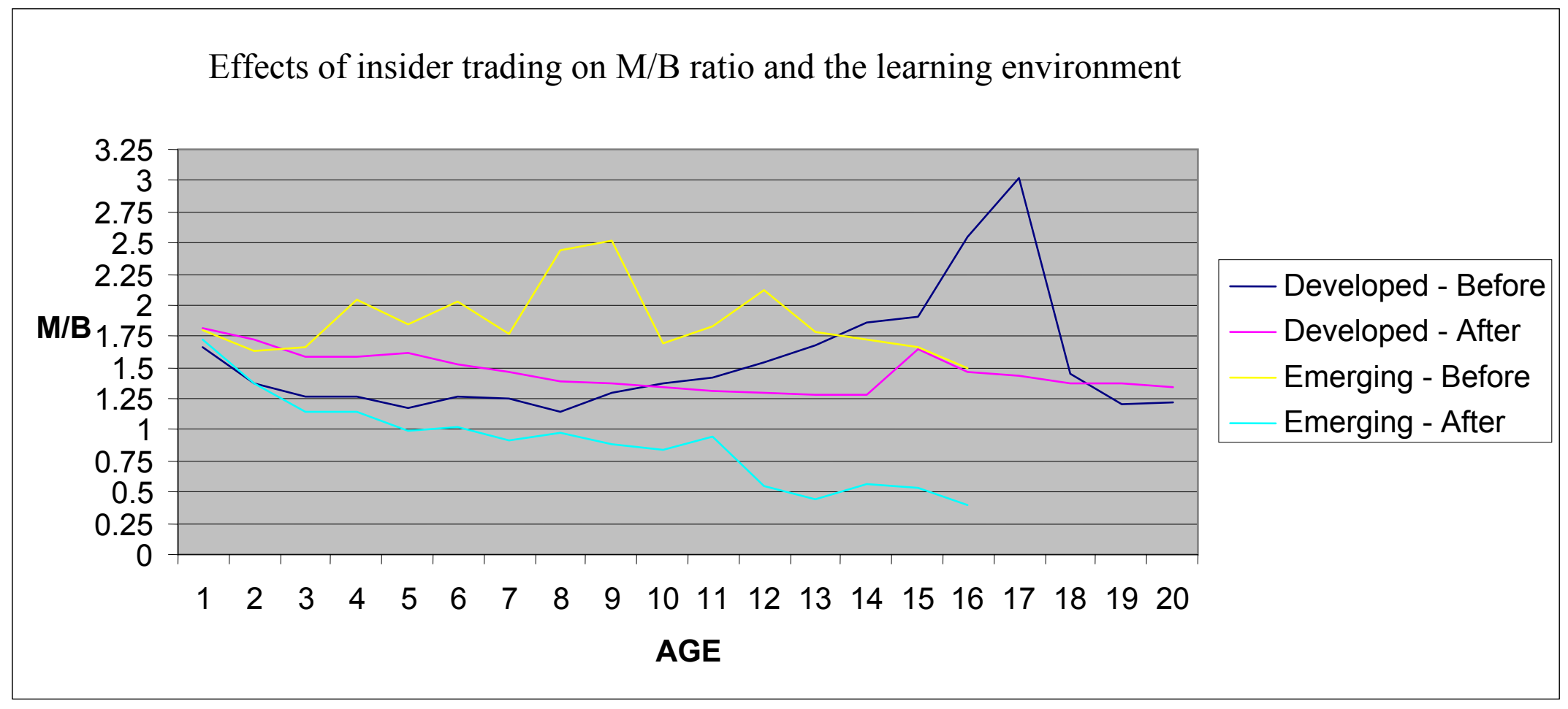

Figure 4 M/B ratio vs Age: Before and After the enforcement of insider trading law as discussed in Bhattacharya and Daouk (2002) 


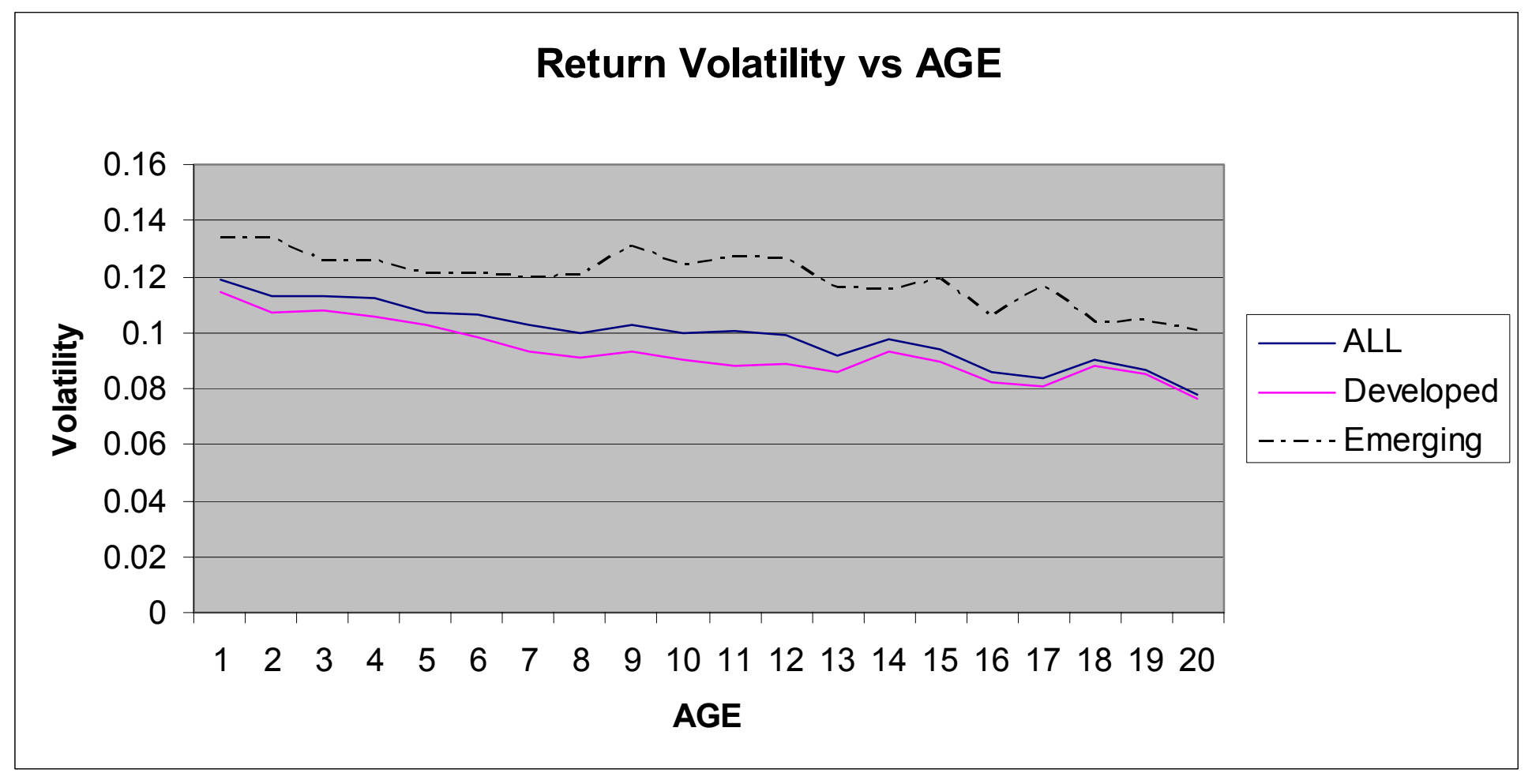

Figure 5 Return volatility vs Age: Developed vs emerging markets 


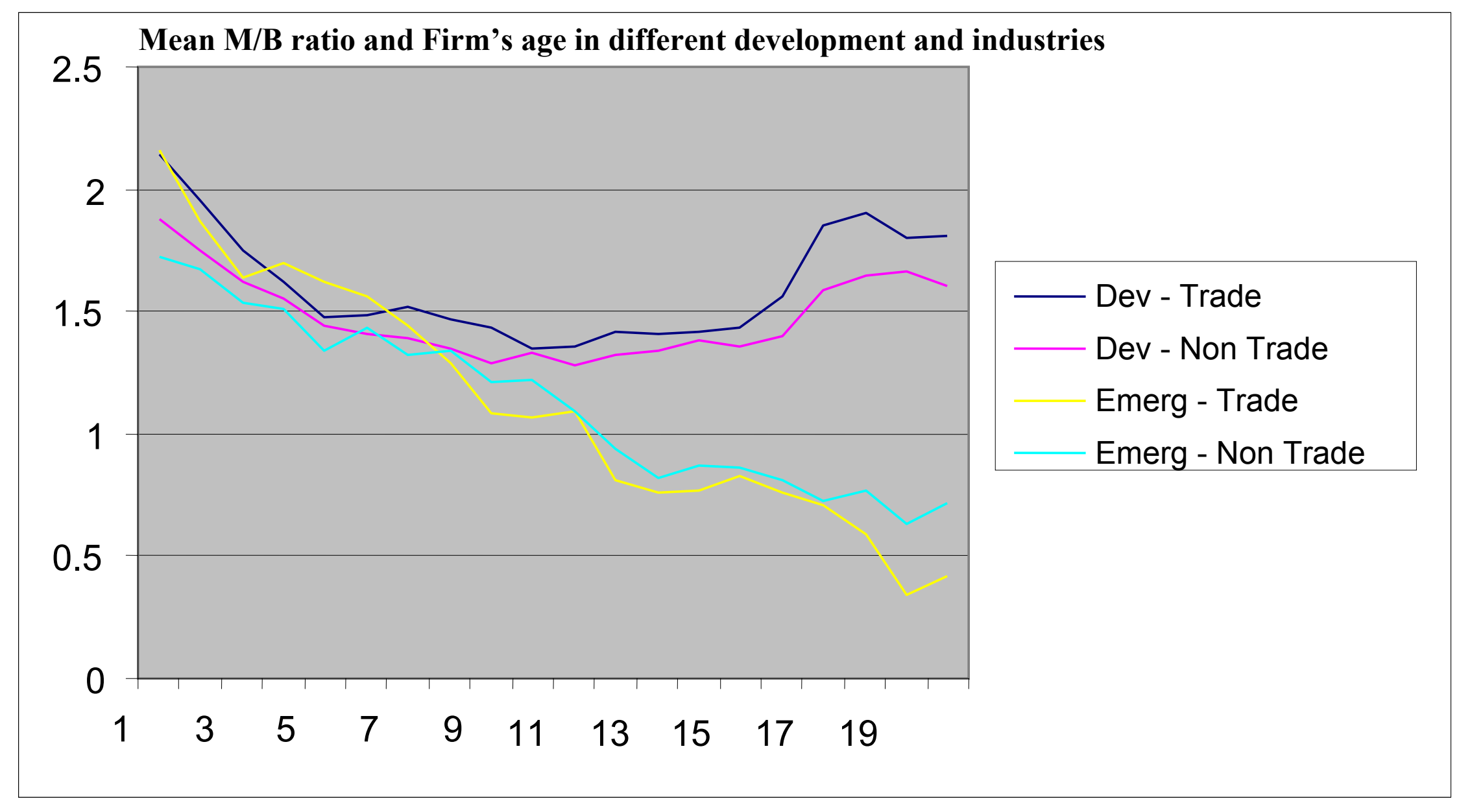

Figure 6: Interaction between economic development and industry characteristics 